Tohoku J. exp. Med., 1977, 121, 121-126

\title{
Further Evidence for the Involvement of Base and Base Sequence in the Antigenic Determination of Thermally Denatured DNA
}

\author{
AKIRA WAKIZAKa and EIJI OKuHARA \\ Department of Biochemistry, Akita University School of \\ Medicine, Akita 010
}

\begin{abstract}
WaKLzaKa, A. and OKUHARA, E. Further Evidence for the Involvement of Base and Base Seguence in the Antigenic Determination of Thermally Denatured DNA. Tohoku J. exp. Med., 1977, 121 (2), 121-126_- The antigenic determinant of thermally denatured salmon sperm (ss) DNA was extensively investigated with a radioimmunoassay technique using the ssDNA immune system. It was demonstrated that mixed sequences of purines and pyrimidines play a key role in the antigenic determination of DNA. On the other hand, the importance of the bases in the manifestation of DNA antigenicity was demonstrated by using brominated, methylated and/or nltraviolet irradiated $\mathrm{ssDNA}$ preparations. - — DNA; antigenic determination; radioimmunoassay
\end{abstract}

The inhibition studies described in the previous paper implied the importance of the base composition or base sequences of the oligonucleotides from DNase digests (Wakizaka and Okuhara 1975a). To elucidate the role of the bases in the manifestation of DNA antigenicity, we planned to use chemically modified and ultraviolet irradiated DNA as antigen. In this paper, we report the results of inhibition studies on the involvement of bases in antigenic determination using the salmon sperm DNA immune system.

\section{Materials and Methods}

The preparation of $\left[{ }^{3} \mathrm{H}\right]$-labeled-DNA, oligonucleotides and antisera to DNA and the measurement of the $\left[{ }^{3} \mathrm{H}\right]$-DNA binding to antibody were performed by the methods described in the previous papers (Matsumoto and Okuhara 1974; Wakizaka and Okuhara 1975a).

Bromination of $D N A$. The bromination of DNA was carried out according to the method of $\mathrm{Yu}$ and Zamecnick (1963): One $\mathrm{ml}$ aliquot of thermally denatured ssDNA solution (2 $\mathrm{mg} / \mathrm{ml}$ of saline), $0.25 \mathrm{ml}$ of $0.4 \mathrm{M}$ bicarbonate buffer $(\mathrm{pH} 9.0$ ) and $0.75 \mathrm{ml}$ of bromine water in a variety of concentrations were mixed. After $10 \mathrm{~min}$ at room temperature, the mixture was applied to a Sephadex $\mathrm{G}-100$ column $(1 \times 30 \mathrm{~cm})$ and eluted with $0.1 \mathrm{M}$ borate buffer $(\mathrm{pH} 8.5)$. The decrease in absorption at $260 \mathrm{~nm}$ was taken as a measure of bromination. Oligonucleotides were also brominated in the same manner. Base composition was analyzed using cation exchange column chromatography (Wakizaka and Okuhara 1975a).

Methylation of DNA. Exhaustively methylated ssDNA (Me-DNA) was prepared with

Received for publication, September $13,1976$. 
dimethyl sulfate according to the method of Pochon and Michelson (1967). The physicochemical properties of the Me-DNA have been described in the previous paper (Igarashi and Okuhara 1976).

Ultraviolet irradiation. Thermally denatured ssDNA solution $(1.0 \mathrm{mg} / \mathrm{ml}$ of saline) in Petri dishes was irradiated by a germicidal lamp (Toshiba GL $15 \mathrm{~W}$ ) at a distance of $5 \mathrm{~cm}$ for various periods.

\section{RESULTS}

Inhibition by various oligonucleotides. First, the inhibitory activity of oligonucleotides from the DNase digests was confirmed by employing five anti-DNA rabbit sera. The haptenic binding inhibition by various oligonucleotides was carried out with these five antisera. As shown in Table I, the oligonucleotides from DNase digests (D-oligo) which contained mixed purine and pyrimidine nucleotide sequences were more highly potent inhibitors than pyrimidine- (Py-oligo) or purine- (Pu-oligo) oligonucleotides.

TABLE 1. Inhibition of $\left[{ }^{3} H\right] D N A$ binding to antibodies by oligonucleotiles

\begin{tabular}{crrr} 
& & & \\
Antiserum No. & D.oligo & Py-oligo & Pu-oligo \\
\cline { 2 - 4 } & $47.2 \pm 8.0$ & $14.6 \pm 3.3$ & $14.4 \pm 3.4$ \\
R72 & $38.3 \pm 4.5$ & $18.1 \pm 4.2$ & $0.6 \pm 0.3$ \\
R74 & $62.9 \pm 2.1$ & $5.2 \pm 0.6$ & $14.5 \pm 4.8$ \\
R116 & $56.4 \pm 5.2$ & $35.8 \pm 1.2$ & $31.1 \pm 3.9$ \\
R117 & $51.7 \pm 1.3$ & $18.3 \pm 2.9$ & $22.8 \pm 7.6$
\end{tabular}

The assay medium contained $1.25 \mu \mathrm{g}$ of thermally denatured mouse embryo $\left[{ }^{3} \mathrm{H}\right]$ DNA $(5,000 \mathrm{dis} . / \mathrm{min} / \mu \mathrm{g})$ and $50 / \mathrm{l}$ of a $1: 50$ dilution of antisera in $0.2 \mathrm{ml}$ of $0.1 \mathrm{M}$ borate buffer $(\mathrm{pH} 8.5)$, and $2.5 \mathrm{~A}_{260}$ units of each oligonucleotide inhibitor was added to the assay medium. Results represent the mean \pm S.E. of three experiments.

Inhibition studies by the use of $B r-D N A$. Fig. 1 shows the results of base analyses of DNA preparations brominated at various concentrations in the range of 0 to $10 \mathrm{mM}$ of bromine. When the concentration of bromine in the reaction mixture was increased, the ultraviolet absorption of DNA gradually decreased. In the recovery of the bases from DNA brominated at $10 \mathrm{mM}$ of bromine, that of adenine increased remarkably, whereas thymine, cytosine and guanine contents decreased compared with those from unbrominated DNA. Fig. 2 shows that the inhibitory activity of brominated DNA on [ $\left.{ }^{3} \mathrm{H}\right]$-DNA binding to antibody decreased markedly with the increase of added bromine, and at the concentration of $2.5 \mathrm{~m}$. of bromine the inhibitory activity was completely lost. Similarly, oligonucleotides from DNase digests were brominated and the inhibition activity was examined and the results are shown in Table 2.

Intibition by Me-DNA. Fig. 3 compares the inhibition activity of Me-DNA with that of non-Me-DNA. In the control assay, $3.0 \mu \mathrm{g}$ of denatured DNA was required for $50 \%$ inhibition, whereas ten times more Me-DNA than non-Me-DNA 


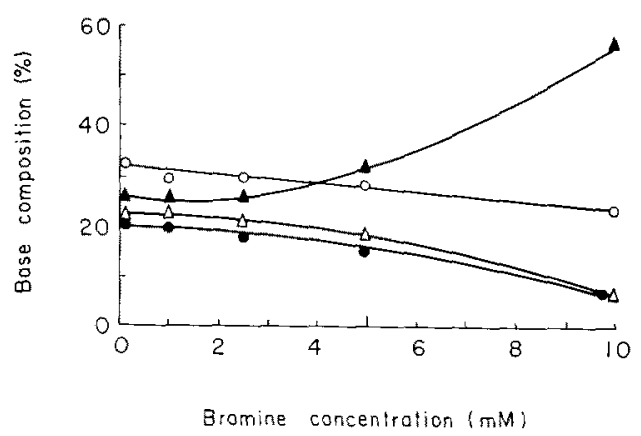

Fig. 1. Base composition of DNA brominated at various concentrations of bromine. $(\wedge)$, adenine; (o), thymine; $(\Delta)$, cytosine; $(\bullet)$, guanine.

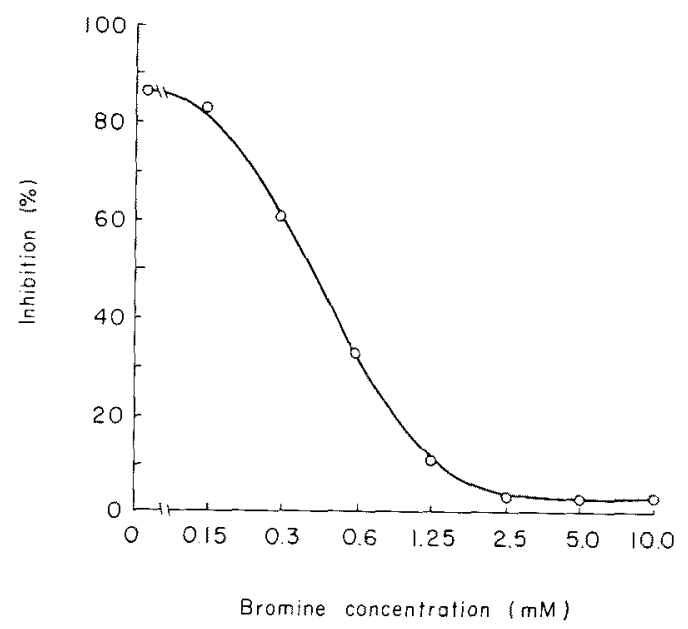

Fig. 2. Inhibition of $\left[{ }^{3} \mathrm{H}\right]-\mathrm{DNA}$ binding to antibody by $\mathrm{Br}-\mathrm{DNA}$. Ten $\mu \mathrm{g}$ of each Br-DNA were added to the assay medium.

TABLE 2. Inhibition of $\left({ }^{3} H / D N A\right.$ binding to antibody by brominated oligonucleotides

\begin{tabular}{ccc}
\hline Deoxynucleotide & Bromination & Inbibition $(\%)$ \\
\hline Pentanucleotide & No & $44.7 \pm 7.2$ \\
Pentanncleotide & Yes & $18.8 \pm 3.1^{*}$ \\
Hexanucleotide & No & $52.5 \pm 4.5$ \\
Hexanucleotide & Yes & $30.3 \pm 2.6 \dagger$
\end{tabular}

* † Statistically significant difference between control and brominated experiments: * $p<0.05$; $\uparrow p<0.01$.

Penta- and hexadeoxynucleotide $\left(20.0 \quad \mathrm{~A}_{2,0}\right.$ units $/ \mathrm{ml}$ respectively) from DNase digests of ssDNA were brominated with $0.3 \mathrm{mM}$ bromine in $50 \mathrm{mM}$ bicarbonate buffer ( $\mathrm{pH} 9.0$ ). Two $A_{260}$ units of the respective oligonucleotide were added to the assay medium. The results represent the mean $t S . \mathrm{E}$. of three experiments. 


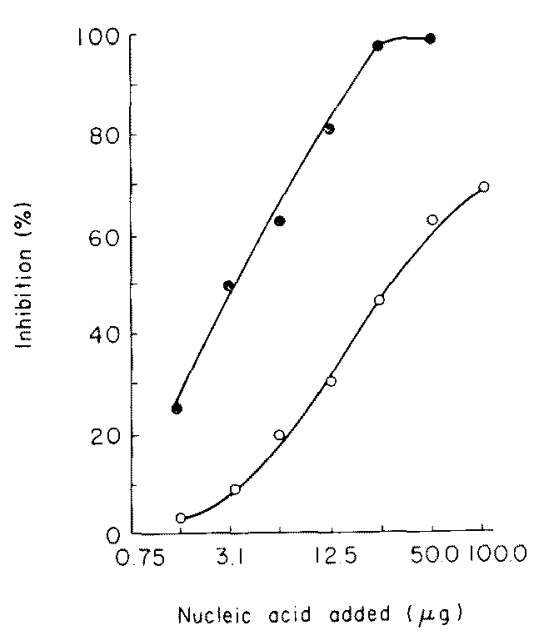

Fig. 3

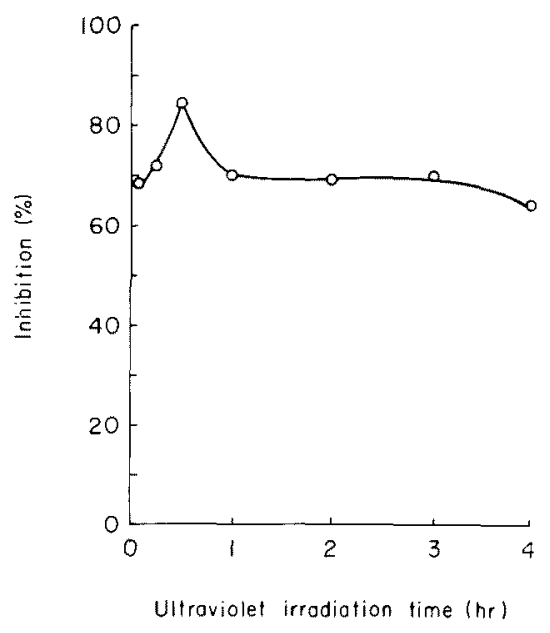

Fig. 4

Fig. 3. Inhibition of $\left[{ }^{3} \mathrm{H}\right]$.DNA binding to antibody by exhaustively methylated DNA. After thermal denaturation, the Me-DNA was added to the assay medium. (o), inhibition by thermally denatured Me-DNA; $\bullet$, by denatured non-Me-DNA.

Fig. 4. Inhibition of $\left[{ }^{3} \mathrm{H}\right]-\mathrm{DNA}$ binding to antibody by ultraviolet irradiated DNA. Ten $\mu g$ of irradiated DNA were added to the assay medium.

was required to obtain the same degree of inhibition.

Inhibition by ultravioletiradiated $D N A$. Thermally denatured ssDNA (1.0 mg/ $\mathrm{ml}$ of saline) was irradiated with ultraviolet and aliquots withdrawn at various times were added to the assay medium for the inhibition tests. As shown in Fig. 4, no significant inhibitory activity was measurable although the DNA irradiated for $30 \mathrm{~min}$ showed a slight increase of inhibition.

\section{DISCUSSION}

As can be seen from the results obtained in the inhibition study, oligonucleotides with mixed purine and pyrimidine sequence showed the highest inhibition activity with the five anti-DNA sera used. The antisera examined were not very susceptible to the inhibition by pyrimidine oligonucleotides, while potent inhibition by pyrimidine nucleotide clusters was observed in human systemic lupus erythematodes sera by Stollar and Levine (Stollar 1968; Levine and Stollar 1968) and by us (Wakizaka and Okuhara 1975b).

According to the proposed mechanism of bromination ( $\mathrm{Yu}$ and Zamecnik 1963; Tung et al. 1974) and methylation (Pochon and Michelson 1967), it is known that the bases are modified in both cases without any destruction of the secondary structure. In the bromination of uridylic acid, the bromine is added to $\mathrm{C}-5$ to form 5-bromo-6-hydroxy-5,6-dihydrouridylic acid. The bromination of other pyrimidine nucleotides appears to proceed in a similar manner. The purine bases are also brominated resulting in the formation of 8-bromoderivatives. Actually we observed that all of the four bases of DNA are brominated to a different extent. 
On the other hand, methylation occurred almost exclusively at the 7-position of the guanine residue on the DNA moleeule. In contrast, ultraviolet irradiation of DNA forms several types of photoproducts (Wacker 1963; Setlow 1968), such as the dimers between adjacent pyrimidine residues which result from the creation of a cyclobutane ring joining two sets of 5,6 double bonds. Practically, such dimers are not formed within the DNA molecule as the antigenic structure is highly affected.

Clearly, the modes of modification are different among these three methods. However, it may be thought that bromination has an effect similar to that of methylation on the structure of the antigen. The extent of inhibitory activity of the modified DNA may be related to the numerical increase in modified bases within the DNA molecule.

Thus the present results provide strong evidence for the involvement of both base and base sequence in the antigenic determination of DNA. Incidentally, it can be said that the chemical modification extensively changes the antigenic structure. The production of antibodies specific for methylated DNA seems to support this (Igarashi and Okuhara 1976).

\section{Acknowledgment}

This work was supported in part by a research grant from the Ministry of Education of Japan.

\section{References}

1) Igarashi, J. \& Okuhara, E. (1976) Preparation of antibodies specific to methylated deoxyribonucleic acid in rabbits. Tohoku J. exp. Med., 120, 25-30.

2) Levine, L. \& Stollar, B.D. (1968) Nucleic acid immune system. Progr. Allergy, 12, 161191.

3) Matsumoto, T. \& Okuhara, E. (1974) Separation and characterization of immunoglobulin classes of anti-salmon sperm deoxyribonucleic acid antibodies in rabbits. Tohoku J. exp. Med., 113, 245-255.

4) Pochon, F. \& Michelson. A.M. (1967) Polynucleotides IX. Methylation of nucleic acids, homopolynucleotides and complexes. Biochim. biophys. Acta (Amst.), 149, 99-106.

5) Setlow, R.B. (1968) The photochemistry, photobiology, and repair of polynucleotides. In: Progress in Nucleic Acid Research and Molecular Biology, eidted by J.N. Davidson \& W.E. Cohn, vol. 8, Academic Press, New York, pp. 257-295.

6) Stollar, D. (1968) DNA and nucleoprotein determinants for systemic lupus erythematosus sera. In: Nucleic Acid in Immunology, edited by O.J. Plescia and W. Braun, Springer-Verlag, New York, pp. 114-124.

7) Tung, F., Kantesaria, P. \& Marfey, P. (1974) Some properties of brominated calf thymus deoxyribonucleic acid. Biochim. biophys. Acta (Amst.), 335, 318-329.

8) Wacker, A. (1963) Molecular mechanisms of radiation effects. In: Progress in Nucleic Acid Research, Edited by J.N. Davidson and W.E. Cohn, vol, 1, Academic Press, New York, pp. 369-399.

9) Wakizaka, A. \& Okuhara, E. (1975a) Immunological studies on nucleic acids: An investigation of the antigenic determinants of denatured deoxyribonucleic acid (DNA) reactive with rabbit anti-DNA antisera by a radioimmunoassay technique. Immunochemistry, 12, 843-845.

10) Wakizaka, A. \& Okuhara, E. (1975b) Immunological studies on the antigenic structure of deoxyribonucleic acid reactive with antinuclear antibodies in sera from patients 
with systemic lupus erythematodes. Proc. Jap. Soc. Immunol., 5, 375-377.

11) Yu, C.T. \& Zameenik, P.C. (1963) Effect of bromination on the amino acid-accepting activities of transfer ribonucleic acids. Biochim. biophys. Acta (Amst.), 76, 209-222. 